\title{
EFEKTIVITAS PELATIHAN REGULASI EMOSI UNTUK MENINGKATKAN RESILIENSI CAREGIVER-KELUARGA PASIEN SKIZOFRENIA
}

\section{EMOTION REGULATION TRAINING EFFECTIVENESS TO IMPROVE THE RESILIENCE OF SCHIZOPHRENIA FAMILY-CAREGIVER}

\author{
R.A. Diana Rahmi Andriani \\ Tina Afiatin \\ Rr. Indahria Sulistyarini \\ Email: d.rahmi.andriani@yahoo.com
}

\begin{abstract}
The study examined the effectiveness of emotion regulation training to improve schizophrenia familycaregiver's resilience. This study use pre-post test control group design. The intervention consist 3 class sessions for two weeks and the duration of every session runs between 150- 180 minutes each. The participants were 10 schizophrenia caregivers from two desa in Moyudan Sleman. They were men and women aged between 39-57 years old, and classified into two groups. One group $(n=5)$ received emotion regulation training as experimental group and the other $(n=5)$ as controlled group (waiting list). Participant were assed using Connor-Davidson Resilience Scale (CD-RISC) before intervention (pre-tes,) after intervention (post-test,) and two weeks after intervention (follow-up). T-test analysis toward the gained score shows difference between the experimental group and controlled group. The experimental group shows significant improvement while the control group show less obvious improvement. The result concluded that emotion regulation training was significantly effective to improve resilience of schizophrenia familycaregiver.
\end{abstract}

Key word: resilience, emotion regulation, schizophrenia family-caregiver

\begin{abstract}
ABSTRAK
Penelitian ini bertujuan untuk menguji efektivitas pelatihan regulasi emosi untuk meningkatkan resiliensi pada caregiver skizofrenia. Penelitian ini mempergunakan desain pra-pasca tes kelompok kontrol dan eksperimen (pre-post test control group design). Perlakuan terdiri dari 3 pertemuan diberikan selama 2 minggu dengan durasi antara 150 menit hingga 180 menit setiap pertemuan. Partisipan dalam penelitian ini adalah 10 orang caregiver skizofrenia berjenis kelamin laki-laki dan perempuan yang berasal dari 2 desa di Kecamatan Moyudan, berusia 39-57 tahun dan dikelompokkan dalam 2 kelompok. Satu kelompok $(n=5)$ sebagai kelompok eksperimen menerima perlakuan berupa pelatihan regulasi emosi. Satu kelompok lainnya $(\mathrm{n}=5)$ sebagai kelompok kontrol (waiting list). Skala Resiliensi CD-RISC (Connor-Davidson Resilience Scale) dipergunakan sebagai alat ukur. Prates disajikan sebelum perlakuan, pascates disajikan setelah perlakuan, dan tindak lanjut (follow up) disajikan setelah 2 minggu perlakuan selesai dilaksanakan. Hasil uji beda mempergunakan t-test terhadap selisih skor menunjukkan perbedaan signifikan antara kelompok eksperimen dan kelompok kontrol. Kelompok eksperimen menunjukkan peningkatan skor resiliensi yang signifikan sedangkan kelompok kontrol justru menunjukkan penurunan skor resiliesi. Dengan demikian dapat disimpulkan bahwa pelatihan regulasi emosi efektif meningkatkan resiliensi pada caregiver-keluarga pasien skizofrenia.
\end{abstract}

Kata kunci : resiliensi, regulasi emosi, caregiver-keluarga pasien skizorenia 


\section{Pendahuluan}

Skizofrenia dikategorikan dalam gangguan kesehatan kronis karena banyak penderita skizofrenia yang mengalami gangguan dengan durasi yang panjang, penderita kurang memiliki insight mengenai gangguan yang dialami, harus melakukan kontrol rutin, serta kerap mengalami relaps. Penderita skizofrenia mengalami gangguan keberfungsiannya oleh karena itu membutuhkan bantuan dari orang lain. Pemberi bantuan dan pertolongan terhadap pasien skizofrenia disebut sebagai caregiver atau carer (Fitrikasari, Kadarman, Woroasih \& Sarjana, 2012). Pemberi perawatan terhadap pasien di rumah sakit adalah pramurawat (Darwin, Hadisukanto, Elvira, 2013), sedangkan pemberi perawatan penderita yang dilakukan di luar rumah sakit (de-institusional) adalah kerabat dan anggota keluarga pasien (Fitrikasari, Kadarman, Woroasih \& Sarjana, 2012).

Banyak penelitian menunjukkan bahwa caregiver skizofrenia setelah keluar dari rumah sakit jiwa mengalami tekanan yang signifikan dan memiliki beban yang tinggi. World Federation of Mental Health menerbitkan laporan yang menggambarkan bahwa menjaga penderita gangguan jiwa kronis membutuhkan usaha tanpa kenal lelah, energi yang besar, empati yang kuat, dan tidak dapat dipungkiri memberikan dampak yang sangat besar terhadap kehidupan seharihari caregiver. Saat para caregiver berjuang untuk menyeimbangkan antara pekerjaan, keluarga, dan menjaga pasien (caregiving), kesehatan fisik dan kesehatan mental mereka terabaikan. Kombinasi antara kurangnya sumber daya personal, finansial, dan emosional, menyebabkan para caregiver mengalami stress berat, depresi, dan atau kecemasan pada tahun saat menjaga pasien dimulai (Chan, 2011).

Selama ini penelitian mengenai keluarga penderita gangguan psikotik lebih banyak fokus terhadap sisi negatif di dalam kehidupan keluarga mereka, misalnya tingginya EE (Expressed Emotion), beban (burden), dan stigma yang diterima oleh keluarga (Subandi, 2011). Caregiver skizofrenia yang mengalami beban berat karena harus merawat anggota keluarganya yang menderita gangguan jiwa, banyak yang mengalami depresi atau gangguan psikologis lainnya. Sebuah studi yang dilakukan di RSJD Amino Gondohutomo Semarang menemukan bahwa $12,9 \%$ dari jumlah subjek penelitian yang merupakan keluarga pasien Skizofrenia mengalami depresi berat (Idaiani, 2003).

Menurut Russo (2012), Rutter (2012), Southwick dan Charney (2012), resiliensi adalah kapasitas dan proses adaptasi yang dinamis dalam menghadapi 
stres dan kesengsaraan (adversity), dengan tetap menjaga keberfungsian fisik dan psikologis (Wu, Feder, Cohen, Kim, Calderon, Charney \& Mathe, 2013). Sedangkan definisi resiliensi pada caregiver penyakit mental serius sangat beragam, namun memiliki persamaan karakteristik yaitu mengatasi kesengsaraan dengan tidak hanya bertahan dengan beban harian untuk merawat anggota keluarga yang mengalami gangguan mental serius, namun maju berkembang, bertumbuh menjadi seseorang yang lebih kuat, lebih fleksibel, dan lebih sehat (Zauszniewski, Bekhet, \& Suresky, 2010). Penelitian Manion (1996) yang menindaklanjuti penelitian Marsh (1996) mengenai efek resiliensi pada anggota keluarga caregiver, menemukan bahwa proses adaptasi, pemulihan, serta resiliensi personal pada kebanyakan (83\%) pasangan hidup penderita gangguan jiwa adalah faktor utama untuk memfasilitasi perubahan positif (Zauszniewski, Bekhet, \& Suresky, 2010).

Reivich dan Shatte (2002) mengemukakan bahwa terdapat tujuh aspek yang membangun resiliensi, yaitu regulasi emosi, pengendalian impuls, optimismen analisis kausal, empati, self efficacy, dan reaching out. APA (American Psychologist Association) juga mengemukakan atribut yang ada di dalam resiliensi adalah 1) kapasitas untuk membuat dan melaksanakan rencana yang realistik, 2) kete- rampilan komunikasi dan memecahkan masalah, 3) pandangan positif atau optimis terhadap hidup, 4) percaya diri atas kekuatan dan kemampuan diri, serta kapasitas untuk mengelola (manage) perasaan, emosi, dan impuls yang kuat (www.apa.org). Berdasarkan dua pendapat di atas, maka dapat disimpulkan bahwa kemampuan mengelola atau meregulasi emosi adalah faktor pembangun resiliensi.

Caregiver penderita gangguan mental serius bertahan menghadapi beban dan stress berat yang dapat menggangu kesehatan dan kualitas hidup serta mengalami gangguan keberfungsian keluarga, jika caregiver menumbuhkan resiliensi maka caregiver dapat mengatasi stres yang dapat diasosiasikan dengan memberikan perawatan bagi penderita gangguan jiwa dan dapat menjaga kesehatan diri sendiri dan keluarga (Zauszniewski, Bekhet, \& Suresky, 2010). Resilensi penting dalam perawatan pasien skizofrenia. Penelitian Subandi (2010) menemukan bahwa resiliensi dan pemberdayaan (empowerment) pada caregiver skizofrenia menentukan kesembuhan (recovery) pasien skizofrenia. Oleh karena, itu jika resiliensi pada caregiver rendah, maka tingkat kesembuhan pasien skizofrenia juga akan rendah.

Hasil studi pendahuluan (preliminary research) menunjukkan bahwa beban berat yang dialami saat memberikan perawatan kepada ODS membuat 
faktor emosional menjadi tinggi. Pada hasil wawancara ditemukan adanya kekerasan fisik terhadap ODS karena marah dengan sikap ODS. Hal ini menunjukkan bahwa caregiver skizofrenia lebih banyak dipengaruhi emosi negatif yang tidak diregulasi dengan baik. Hasil studi pendahuluan (preliminary research) juga menunjukkan bahwa kondisi penuh tekanan yang dialami caregiver-keluarga skizofrenia menyebabkan caregiverkeluarga rentan mengalami gangguan fisik dan psikologis. Kondisi emosi yang tidak stabil mempengaruhi pikiran, perilaku dan reaksi fisiologis. Berdasarkan kondisi tersebut maka dasar teori untuk memberikan perlakuan yang tepat terhadap kondisi caregiver tersebut adalah teori $\mathrm{ABC}$ dari Albert Ellis.

Teori ABC yang dikemukakan oleh Albert Ellis berpendapat bahwa proses berpikir, proses emosi, dan aksi memiliki hubungan interaksional. Teori ABC menekankan hubungan antara A (Activating event-peristiwa pendahulu), B (Beliefkeyakinan) dan C (Consequences-konsekuensi) adalah hubungan yang berputar (cyclical). Hubungan interaksional antara keyakinan (B) dan emosi (dan juga perilaku) merujuk pada hubungan hubungan keyakinan (B) dan konsekuensi (C) dalam model teori $A B C$. Model ini memiliki postulat bahwa konsekuensi emosional tidak ditentukan oleh peristiwa pendahulu (A) namun lebih ditentukan oleh keya- kinan (B) mengenai situasi yang dihadapi tersebut. Teori $\mathrm{ABC}$ menekankan bahwa proses pikir, emosi, dan perilaku terjadi secara bersamaan dalam merespon suatu peristiwa (Malkinson, 2007). Intervensi bagi caregiver skizofrenia yang memiliki resiliensi rendah dan berorientasi tidak hanya pada emosi namun juga pikiran dan perilaku yang sesuai dengan pendekatan teori $A B C$ Albert Ellis adalah pelatihan regulasi emosi. Pelatihan regulasi emosi bertujuan untuk memberikan keterampilan regulasi emosi. Keterampilan regulasi emosi diawali dengan keterampilan mengenali emosi, dan kemudian keterampilan mengekspresikan emosi. Kedua proses tersebut berorientasi pada aspek pikiran. Keterampilan mengelola emosi yang dilakukan dengan teknik relaksasi untuk menenangkan diri merupakan proses yang berorientasi pada perilaku. Sedangkan untuk mengubah emosi negatif menjadi positif, proses yang dilakukan melibatkan aspek pikiran dengan melakukan self talk, emosi, dan perilaku. Bernard (2008) telah melakukan penelitian mengenai pelatihan regulasi emosi untuk meningkatkan resiliensi pada anak yang merujuk kepada teori dari Ellis, Lazarus, Meichenbaum, dan Seligman.

Regulasi emosi adalah kemampuan untuk mengendalikan emosi. Apabila seseorang memiliki kemampuan mengelola emosi yang baik, maka akan memiliki reaksi emosional yang positif. Kemam- 
puan regulasi emosi yang baik akan berpengaruh pada meningkatnya kemampuan mengontrol emosi dengan cara menghambat respon emosi negatif. Kondisi tersebut memungkinkan caregiver untuk lebih bisa memahami perilaku pasien skizofrenia. Mereka juga lebih mampu memberikan penilaian tentang situasi yang sedang dihadapi untuk menurunkan dampak emosional. Efek dari kondisi tersebut akan menghasilkan reaksi emosional yang positif, sedangkan kemampuan regulasi emosi yang kurang baik akan cenderung menghasilkan emosi negatif dan kemudian juga diekspresikan melalui perilaku marah atau kesal bahkan perilaku agresif (Makmuroch, 2014). Selain untuk menurunkan dampak emosional yang negatif, regulasi emosi memberikan efek positif terhadap resiliensi. Hal ini sesuai dengan penelitian Vanderbilt-Adriance dan Shaw (2008) yang mengemukakan bahwa regulasi emosi adalah faktor protektif yang sama pentingnya dengan IQ (Kecerdasan Kognitif) dan pola asuh nurturant (pola asuh yang hangat, menerapkan disiplin konsisten, responsif, terstruktur, dan terpantau), hubungan anak dan orangtua, serta, hubungan antar orangtua pada anakanak yang hidup pada lingkungan yang beresiko tinggi.

Resiliensi adalah sisi positif dari perbedaan individu dalam merespon kesengsaraan (adversity). Depresi dan gangguan kecemasan sering kali diasosiasikan dengan resiliensi. Penelitian menemukan bahwa kedua gangguan tersebut dapat dibantu dengan intervensi pengembangan resiliensi. Dari beberapa karakteristik yang meningkatkan resiliensi, bentuk kognitif positif dari regulasi emosi ditemukan sebagai perantara penting resiliensi. Hal tersebut berdasarkan pengamatan bahwa transformasi kognitif diasosiasikan dengan meningkatnya resiliensi dalam menghadapi kejadian di dalam hidup. Regulasi emosi adalah proses ekstrinsik dan intrinsik yang bertanggung jawab untuk memonitor, mengevaluasi dan memodifikasi reaksi emosional khususnya pada intensitas dan fitur temporal untuk mencapai tujuan tertentu. Regulasi emosi penting untuk menentukan keberfungsian dan adaptasi, karena kegagalan meregulasi emosi, ditengarai sebagai bentuk konstruk bebas yang dapat menyebabkan berbagai simtom psikiatri dan gangguan (disorder). Walaupun regulasi emosi melibatkan baik kognitif secara sadar (conscious) dan tidak sadar (unconscious), proses secara sadar lebih memberikan target yang berguna untuk intervensi dengan cara mengajarkan keterampilan manajemen kognitif dari informasi yang membangkitkan emosi dan rencana aksi. Beberapa penelitian melaporkan bahwa strategi kognitif adaptif dalam regulasi emosi seperti pemaknaan kembali yang positif, penerimaan, pengambilan jarak yang positif dan 
perencanaan masa depan berhubungan erat dengan resiliensi (Min, Yoon, Lee, Chae, Lee, Song \& Kim, 2013)

Gross dkk (Tugade \& Frederickson, 2007) menemukan bahwa cara regulasi ekspresi emosi yang positif dapat menurunkan pengaruh dari emosi negatif, setidaknya untuk kurun waktu tertentu yang singkat. Walaupun memodifikasi aspek perilaku (misalnya, ekspresi wajah) dari emosi dapat menciptakan perbedaan (discrepancy) antara pengalaman hati dan ekspresi yang ditampakkan, namun hal tersebut memiliki pengaruh penting dalam keberfungsian emosi. Tersenyum saat merasa sedih, dapat mempercepat kepulihan cardiovascular yang disebabkan oleh emosi negatif.

Sebuah penelitian berusaha menemukan keuntungan fisiologis dan psikologis untuk meningkatkan atau memperkaya pengalaman emosi positif. Menurut Folkman dan Moskowitz (2000), satu strategi penting untuk untuk menemukan arti positif dalam kejadian negatif, yang memproduksi emosi positif akan membantu melawan stres yang muncul. Individu menemukan arti positif dalam kehidupan sehari-hari melalui berbagai macam cara, yaitu (1) penilaian positif (positive appraisal), (2) koping yang berorientasi pada pemecahan masalah (problem focused coping), dan memberikan peristiwa yang biasa atau sederhana dengan arti positif. Penelitian
Folkman dan Moskowitz (2000), pada caregiver penderita AIDS, menemukan bahwa walaupun dalam kondisi stres lebih dari 99\% partisipan dapat menemukan arti positif dalam kondisi yang biasa dan sederhana (ordinary). Para caregiver melihat aspek positif di dalam hidup mereka sebagai cara untuk menghadapi stres yang dialaminya. Emosi positif berperan penting dalam proses tersebut, penilaian positif (positive appraisal) menciptakan pengalaman emosi positif meski dalam kondisi stres. Sebagai hasilnya, pengalaman emosi positif tersebut dapat memberikan dorongan psikologis yang dibutuhkan yang membantu individu untuk meneruskan hidup mereka (Tugade \& Frederickson, 2007).

Pelatihan regulasi emosi yang sesuai dengan teori Greenberg (2002) mencakup empat keterampilan yang akan diajarkan, yaitu keterampilan mengenali emosi, keterampilan mengekspresikan emosi, keterampilan mengelola emosi, dan keterampilan mengubah emosi negatif menjadi emosi positif. Masing-masing keterampilan tersebut memiliki pengaruh terhadap resiliensi.

Keterampilan mengenali emosi membantu mengidentifikasi emosi primer dan emosi maladaptif. Emosi primer perlu diakses dalam kesadaran untuk mendapatkan informasi adaptif dan kapasitasnya untuk mengorganisir tindakan. Informasi adaptif dan kapasitas untuk mengorganisir 
tindakan yang didapat dari emosi primer ini akan membantu proses koping aktif. Koping aktif adalah penggunaan teknik perilaku dan fisiologis untuk mengurangi atau mengatasi stres, dihubungkan dengan resiliensi (Wu, Feder, Cohen, Kim, Calderon, Charney \& Mathe, 2013). Emosi maladaptif perlu diakses dengan tujuan agar dapat dirubah dalam sebuah proses yang membawa emosi maladaptif ke pengalaman yang baru dan memberi makna baru. Pemberian makna baru ini disebut juga reappraisal atau reframing. McRae (2012) menemukan bahwa cognitive reappraisal, sangat kuat diasosiasikan dengan resiliensi (Wu, Feder, Cohen, Kim, Calderon, Charney \& Mathe, 2013). Keterampilan mengekspresikan emosi memfasilitasi pemahaman pikiran dan perasaan secara koheren. Pennebaker (1995), Rime dkk (1998) menemukan bahwa melalui bahasa, individu dapat mengorganisir, menstrukturisasi serta mengasimilasi pengalaman emosional dan kejadian yang dapat memunculkan emosi. Ketika emosi diekspresikan, individu dapat merefleksikan apa yang dirasakan, menciptakan makna baru, mengevaluasi pengalaman emosionalnya sendiri, serta berbagi pengalamannya dengan orang lain. Saat seseorang memiliki sense of coherence, maka dapat disebut memiliki resiliensi karena sense of coherence adalah salah satu indikator resiliensi.
Keterampilan mengelola emosi dengan mempergunakan satu teknik yang digunakan dalam mengelola emosi yaitu relaksasi dapat membantu untuk mengurangi ketegangan dan kecemasan. Saat ketegangan dan kecemasan berkurang maka kemampuan mentoleransi emosi menjadi baik karena dapat membangun jarak kerja (a working distance, memisahkan diri dari emosi yang berlebihan sehingga dapat melihat situasi dengan lebih baik dan dapat melakukan koping), meningkatkan emosi positif, mengurangi kerentanan terhadap emosi negatif (Greenberg \& Pascual-Leone, 2006). Hal tersebut dapat menjadi faktor protektif pembangun resiliensi (Troy \& Mauss, 2010)

Keterampilan mengubah emosi negatif menjadi positif memberikan pengaruh terhadap resiliensi karena emosi positif dapat menghentikan atau meminimalkan dampak emosi negatif yang dihadapi saat menghadapi stres. Frederickson (Greenberg, 2004) mengidentifikasikan fungsi adaptif dari emosi. Emosi positif meningkatkan kemampuan pemecahan masalah dengan membuat proses berfikir lebih fleksibel, kreatif dan efisien. Frederickson juga menemukan bahwa emosi positif membangun resiliensi dengan membatalkan efek dari emosi negatif. Penemuan ini menjadi penting karena relevansinya bagi pemulihan dari efek self-critism. Penelitian Davidson 
(2000) dalam neuropsikologi menemukan bahwa afek positif yang stabil membangun resiliensi psikologis. Kemampuan untuk mengumpulkan emosi positif saat menghadapi stres merupakan komponen penting bagi resiliensi (Greenberg, 2004).

Teori ABC memiliki pandangan bahwa meskipun peristiwa atau kemalangan (A) secara signifikan berkontribusi terhadap konsekuensi emosional dan perilaku (C), keyakinannya (B) tentang $A$ lebih penting dan langsung menyebabkan C. Peristiwa dimana caregiver skizofrenia merawat pasien skizofrenia (A) akan memunculkan konsekuensi baik positif maupun negatif. Konsekuensi tersebut bergantung kepada keyakinan (B) yang ada di dalam diri caregiver.

Keyakinan (B) muncul dalam proses internal self-talk. Self-talk adalah dialog internal dimana orang berbicara mengenai segala sesuatu dengan dirinya sendiri saat menginterpretasikan peristiwa-peristiwa yang terjadi pada dirinya. Self-talk terbagi menjadi dua, yaitu self-talk positif dan self-talk negatif. Self-talk positif adalah ide-ide atau pemikiran yang rasional, sedangkan self-talk negatif adalah ide-ide atau pikiran yang tidak rasional atau irasional. Menurut asumsi teori $\mathrm{ABC}$, self-talk negatif berhubungan secara kausal dengan gangguan-gangguan emosional dan behavioral. Cara yang efisien untuk mengubah self-talk negatif dengan mengkonfrontasi secara langsung filsafat hidup mereka sendiri dan mengajari bagaimana berfikir secara logis sehingga mampu menghapus keyakinankeyakinan (B) irasionalmya (Iswari \& Hartini, 2005). Self-talk dapat diubah menjadi pernyataan-pernyataan yang sehat dan logis sehingga terjadi proses perubahan kognitif (cognitive restructuring) (Emilia, 2014).

Pelatihan regulasi emosi yang akan diberikan kepada caregiver skizofrenia mempergunakan dasar pemikiran teori ABC Albert Ellis dengan memberikan proses pelatihan dengan metode aktif direktif dimana terapis atau fasilitator berperan untuk mengajari klien cara-cara memahami dan mengubah diri. Teori $A B C$ terutama dipergunakan dalam sesi mengubah emosi negatif menjadi positif. Proses mengubah emosi positif menjadi negatif diawali dengan menjelaskan proses reaksi terhadap situasi yang dihadapi (A - Activating event - peristiwa pendahulu), menyebabkan munculnya pikiran (B- Belief- keyakinan) dan pikiran (B- Belief- keyakinan) kemudian mempengaruhi emosi dan perilaku (C-Consequences- konsekuensi) sebagai hasil dari B. Kejadian yang dihadapi (A - Activating event - peristiwa pendahulu) tidak menyebabkan perilaku dan emosi negatif (C-), namun pikiran (B- Belief- keyakinan) negatif menyebabkan konsekuensi negatif berupa emosi dan perilaku negatif (C-). Oleh karena itu jika pikiran positif $(B+)$, 
emosi dan perilaku dapat menjadi positif $(\mathrm{C}+)$. Cara untuk mengubah pikiran yang negatif adalah dengan mempergunakan self-talk. Pikiran negatif (B-) muncul karena self talk negatif, oleh karena itu self talk negatif diubah dengan mengkon- frontasi secara langsung filsafat hidup mereka sendiri (D- Dispute) dan mengajari bagaimana berfikir secara logis sehingga mampu menghapus keyakinankeyakinan (B) irasionalmya.

\section{Bagan Kerangka Teoritis}

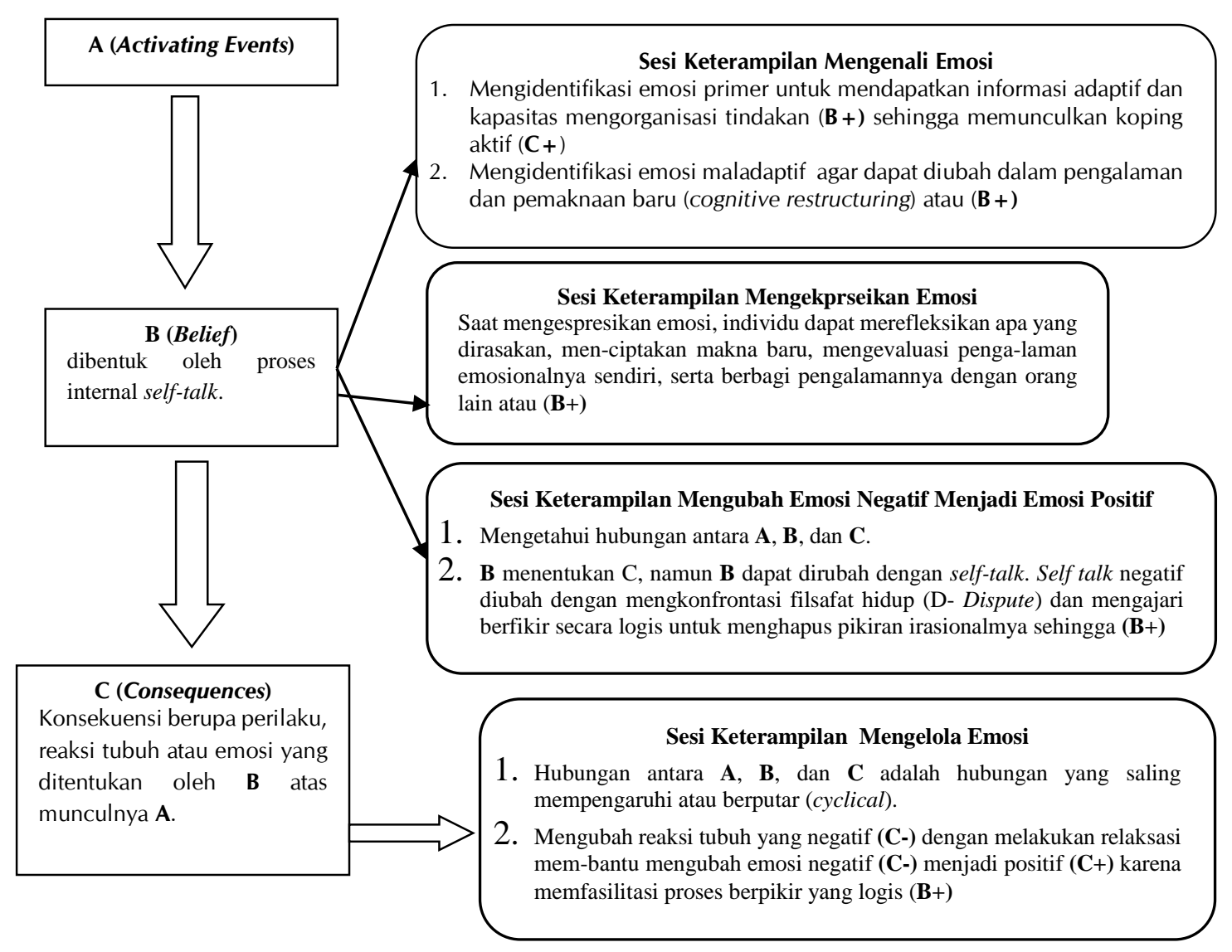

\section{Keterangan :}

Hubungan interaksional teori $\mathrm{ABC}$ Albert Ellis

$\longrightarrow \quad$ Memodifikasi elemen ABC dengan Pelatihan Regulasi Emosi

(berdasarkan teori Greenberg, 2002) 


\section{HIPOTESIS}

Hipotesis dalam penelitian ini adalah ada perbedaan peningkatan resiliensi pada caregiver skizofrenia yang mendapat Pelatihan Regulasi Emosi (Kelompok Eksperimen) dibandingkan dengan yang tidak mendapat Pelatihan Regulasi Emosi (Kelompok Kontrol).

\section{METODE PENELITIAN}

Penelitian ini menggunakan metode kuasi-eksperimen. Campbell dan Stanley (1979) merumuskan eksperimen kuasi sebagai sebuah eksperimen yang mempunyai perlakuan (treatments) pengukuran dampak perlakuan (outcome measures), dan unit eksperimen (experimental units), namun tidak menggunakan penempatan secara acak (nonrandom assignment). Eksperimen kuasi mempunyai tujuan yang sama dengan eksperimen acak, yaitu menguji hipotesis kausal deskriptif mengenai sebab yang dimanipulasi. Eksperimen kuasi memiliki struktur yang sama dengan eksperimen acak, seperti adanya pengukuran prates, pascates atau kelompok kontrol untuk menegakkan inferensi/kesimpulan kontrafaktual. Akan tetapi fitur pembeda eksperimen kuasi adalah tidak adanya penempatan unit secara acak ke dalam kelompok eksperimen dan kelompok kontrol (Hastjarjo, 2014).
Pengumpulan data dalam penelitian ini dilakukan melalui metode wawancara, observasi, dan skala psikologi. Variabel resiliensi diukur dengan menggunakan skala resiliensi CD-RISC 25 item yang sudah terbukti sebagai salah satu skala untuk mengukur resiliensi terbaik menurut penelitian Windle, Bennet \& Noyes (2011). CD-RISC 25 item ini memuat lima aspek, yaitu 1) kompetensi personal yang terkait dengan kegigihan, 2) toleransi terhadap situasi yang tidak menyenangkan, 3) penerimaan positif terhadap perubahan dan hubungan sosial yang terjaga, 4) kemampuan untuk mengendalikan situasi, dan 5) spiritualitas. CD-RISC 25 item ini telah diadaptasi ke dalam bahasa Indonesia dan telah diuji validitas dan realiabilitas alat ukurnya oleh Khairiyah (2013) dalam penelitiannya. Validitas instrument dikatakan memberikan kontribusi yang baik ketika indeks daya diskriminsi $\geq 0,3$ (Azwar, 2005). Hasil uji coba menemukan terdapat tiga item yang memiliki koefisin di bawah 0,3 , yaitu item no $5(0,283)$, item no $18(0,137)$, dan item no 20 ($0,030)$. Dengan demikian terdapat 22 item yang valid. Reliabilitas CD-RISC 22 item setelah uji coba adalah 0,924 (Khairiyah, 2013).

Teknik analisis data utama yang akan digunakan dalam penelitian ini adalah pendekatan kuantitatif, selain itu peneliti juga akan menggunakan teknik analisis data kualitatif yang dilakukan 
terhadap hasil observasi dan wawancara. Analisis data kuantitatif menggunakan software Statistical Product and Service Solution (SPSS) versi 16.00. Uji hipotesis menggunakan analisis parametrik independent sample t-test terhadap selisih skor (gained score)

Subjek dari penelitian ini adalah anggota keluarga caregiver pasien ski- zofrenia. Jumlah subjek dalam penelitian ini adalah 10 orang, yang dibagi menjadi dua kelompok yaitu lima orang subjek menjadi kelompok eksperimen dan lima orang subjek menjadi kelompok kontrol. Berikut ini adalah data subjek dalam penelitian ini:

Tabel 1. Subjek Penelitian

\begin{tabular}{rlcccc}
\hline No & Nama & Usia & Pendidikan & $\begin{array}{c}\text { Hubungan dengan Penderita } \\
\text { Skizofrenia }\end{array}$ & Kelompok \\
\hline 1 & Sty & 46 & SMP & Istri & Eksperimen \\
2 & MH & 49 & SD & Suami & Eksperimen \\
3 & Rby & 39 & SMA & Adik & Eksperimen \\
4 & Rbn & 50 & SD & Adik & Eksperimen \\
5 & Slt & 41 & SMA & Adik & Eksperimen \\
6 & Myt & 54 & SD & Ibu & Kontrol \\
7 & Spr & 54 & SMP & Ibu & Kontrol \\
8 & Kwt & 57 & SD & Ayah & Kontrol \\
9 & Sry & 48 & SMA & Ayah & Kontrol \\
10 & Mmy & 44 & SMA & Suami & Kontrol \\
\hline
\end{tabular}

\section{HASIL PENELITIAN}

Analisis untuk uji hipotesis menggunakan t-test karena uji asumsi diketahui bahwa data yang didapatkan normal dan homogen, sehingga analisis parametrik dapat dilakukan. Data yang dianalisis berdasarkan skala resiliensi CDRISC pada tahap prates, pasca tes, dan tindak lanjut pada kelompok eksperimen dan kontrol. Berikut adalah hasil uji beda mempergunakan t-test terhadap selisih skor (gained score) 
Tabel 2. Uji Beda dengan Menggunakan Gained Score Resiliensi

\begin{tabular}{lrrrc}
\hline Pengukuran & $\mathbf{X}_{\mathrm{GE}}$ & $\mathbf{X}_{\mathrm{GK}}$ & $\mathbf{T}$ & $\mathbf{P}$ \\
\hline $\mathrm{G}_{1}$ & 13,60 & $-0,20$ & 2,299 & 0,043 \\
$\mathrm{G}_{2}$ & 4,20 & $-2,00$ & 1,588 & 0,151 \\
$\mathrm{G}_{3}$ & 17,80 & -2.20 & 2,918 & 0,019 \\
\hline
\end{tabular}

Keterangan

G1 : Selisih skor pra dan pascates

$\mathrm{G}_{2} \quad$ : Selisih skor pascates dan tindak lanjut

G $\quad$ : Selisih skor prates dan tindak lanjut

$\mathrm{X}_{\mathrm{GE}} \quad$ : Peningkatan rata-rata kelompok eksperimen

$\mathrm{X}_{\mathrm{GK}} \quad$ : Peningkatan rata-rata kelompok kontrol

Berdasarkan tabel di atas, pengukuran $\mathrm{G}_{1}$ diperoleh $\mathrm{p}=0.043(\mathrm{p}<0.05)$. Hal tersebut menunjukkan bahwa ada perbedaan signifikan peningkatan ratarata resiliensi saat prates dan pascates. Peningkatan rata-rata skor resiliensi pada kelompok eksperimen lebih tinggi $(13,60)$ dibandingkan dengan kelompok kontrol ($0,20)$. Hasil pengukuran $\mathrm{G}_{2}$ diperoleh $\mathrm{p}=$ 0.151 ( $p>0.05$ ). Hal tersebut menunjukkan bahwa tidak ada perbedaan signifikan peningkatan rata-rata resiliensi saat pascates dan tindak lanjut. Namun, peningkatan rata-rata skor resiliensi pada kelompok eksperimen lebih tinggi $(4,20)$ dibandingkan dengan kelompok kontrol ($2,00)$. Hasil pengukuran $\mathrm{G}_{3}$ diperoleh $\mathrm{p}=$ 0.019 ( $p<0.05)$. Hal tersebut menunjukkan bahwa terdapat perbedaan signifikan peningkatan rata-rata resiliensi saat prates dan tindak lanjut. Peningkatan ratarata skor resiliensi pada kelompok eksperimen lebih tinggi $(17,80)$ dibandingkan dengan kelompok kontrol $(-2,20)$.
Berdasarkan hasil uji hipotesis di atas, maka dapat disimpulkan bahwa Pelatihan Regulasi Emosi terbukti secara signifikan dapat meningkatkan resiliensi caregiver skizofrenia.

\section{PEMBAHASAN}

Penelitian ini bertujuan untuk menguji hipotesis pelatihan regulasi emosi akan meningkatkan resiliensi pada caregiver skizofrenia. Pengukuran resiliensi dilakukan sebelum dan sesudah pelatihan regulasi emosi diberikan, serta pada periode tindak lanjut (follow up) pada kelompok eksperimen dan kontrol. Hasil uji beda mempergunakan t-test terhadap selisih skor (gained score) menunjukkan perbedaan signifikan antara kelompok eksperimen dan kelompok kontrol $(\mathrm{t}=2,399$ dan $\mathrm{p}=0.043, \mathrm{p}<$ 0.05). Kelompok eksperimen menunjukkan peningkatan skor resiliensi yang signifikan $\left(X_{\mathrm{GE}}=13,60\right)$, sedangkan 
kelompok kontrol justru menunjukkan penurunan skor resiliesi $\left(X_{\mathrm{GK}}=-0,20\right)$.

Menurut pendapat Dong, Nelson, Shah-Haque, Khan, dan Ablah (2013), resiliensi dipengaruhi oleh gender, latar belakang etnik dan budaya, serta tingkat pendidikan. Kelompok eksperimen terdiri dari tiga orang subjek perempuan dan dua orang subjek laki-laki. Sedangkan kelompok kontrol terdiri dari dua subjek perempuan dan empat subjek orang lakilaki. Perubahan skor subjek perempuan pada kelompok eksperimen (Rby) tidak terlalu besar dibandingkan perubahan skor subjek laki-laki dalam kelompok eksperimen (SIt dan $\mathrm{MH}$ ) dan kelompok kontrol (Kwt), Hal ini sesuai dengan penelitian $\mathrm{Ni}$, Chow, Jiang, $\mathrm{Li}$, Mei, dan Pang (2015) menemukan bahwa tingkat resiliensi laki-laki lebih tinggi dibandingkan perempuan pada survivor gempa Sichuan 2008, penelitian Yu (2007) yang menemukan bahwa laki-laki memiliki skor resiliensi yang lebih tinggi dibandingkan perempuan pada komunitas Cina, dan penelitian Tolin dan Foa (2006) bahwa baik dalam desain penelitian ataupun dalam populasi, perempuan memperlihatkan tingkat PTSD yang lebih tinggi dibandingkan laki-laki, hal ini menunjukkan bahwa resiliensi yang rendah pada wanita setelah mengalami trauma.

Berdasarkan perbandingan rata-rata hasil prates, pascates, dan tindak lanjut antara kelompok eksperimen dan kelompok kontrol terdapat peningkatan ratarata skor pada kelompok eksperimen dan kelompok kontrol. Perubahan skor berupa kenaikan skor pada kelompok kontrol dapat disebabkan oleh faktor eksternal yang tidak dapat dikontrol peneliti selama melaksanakan penelitian misalnya adanya dukungan sosial yang didapatkan oleh subjek kelompok kontrol saat penelitian berlangsung. Hal ini ditunjukkan dari hasil wawancara saat tindak lanjut terhadap pak Kwt. Dukungan berupa obat-obatan yang selama ini didapatkan dari RSJ Grashia, dapat ditebus di puskesmas mempermudah Pak Kwt dalam memberikan perawatan pada pasien. Dukungan sosial termasuk ke dalam faktor psikologis yang mempengaruhi terbentuknya resiliensi menurut $\mathrm{Wu}$, Feder, Cohen, Kim, Calderon, Charney dan Mathe (2013).

Berdasarkan hasil analisis kualitatif, ditemukan bahwa subjek yang mengalami peningkatan skor resiliensi cukup tinggi (Rbn), mendapatkan dukungan sosial berupa saran dari sesama peserta pelatihan mengenai bagaimana memberikan perawatan terhadap pasien skizofrenia. Koping spiritual juga mempengaruhi peningkatan skor resiliensi yang cukup tinggi (Rbn dan Sty). Skor prates subjek yang sudah tinggi (SIt), mengalami peningkatan namun tidak terlalu besar peningkatannya. Subjek yang mengalami 
peningkatan skor saat pascates namun tidak mengalami peningkatan saat tindak lanjut, (Rby) mengalami hambatan dalam memberikan perawatan terhadp kakak kandungnya karena baru saja menikah satu tahun ini. Sedangkan subjek yang mengalami penurunan skor resiliensi $(\mathrm{MH})$, memiliki permasalahan yang baru diketemukan saat tindak lanjut. $\mathrm{MH}$ masih berpikir keluarga istri berbohong mengenai kondisi istrinya saat akan menikahinya. Selain itu MH merasa marah dan kecewa karena sering disalahkan jika istrinya kumat.

\section{SIMPULAN DAN SARAN}

Kesimpulan dari penelitian ini adalah terdapat perbedaan tingkat resiliensi yang signifikan antara caregiver yang mendapat pelatihan regulasi emosi dan yang tidak mendapatkannya. Pelatihan Regulasi Emosi terbukti efektif untuk meningkatkan. resiliensi pada caregiver skizofrenia. Hal ini dapat diketahui dari perbedaan skor yang didapatkan sebelum dan sesudah pelatihan regulasi emosi dilaksanakan. Kelompok eksperimen mengalami peningkatan skor resiliensi secara signifikan dibandingkan dengan kelompok kontrol yang tidak mendapatkan pelatihan regulasi emosi.

Para subjek penelitian disarankan untuk tetap menjalin komunikasi dengan sesama peserta pelatihan. Interaksi yang intens dapat membantu subjek untuk tetap mengingat pengetahuan yang telah didapatkan dari pelatihan. Selain itu inetraksi antar peserta pelatihan dapat menjadi wadah untuk mengekspresikan emosi dengan cara berbagi dan diskusi mengenai bagaimana memberikan perawatan kepada penderita skizofrenia. Interaksi akan mendorong subjek untuk terus saling mendukung dan mengembangkan sikap positif. Pengetahuan yang dimiliki subjek juga diharapkan dapat diteruskan pada individu lain yang menghadapi kondisi yang sama. Subjek yang masih memiliki kendala dalam memberikan perawatan pada pasien skizofrenia atau mengalami gangguan psikologis lain diharapkan mendapatkan intervensi individual.

Kelemahan penelitian ini adalah subjek yang hetergogen. Subjek pada kelompok eksperimen dalam penelitian ini adalah caregiver skizofrenia dengan rentang usia 38-57 tahun, berjenis kelamin laki-laki dan perempuan serta memiliki latar belakang pendidikan yang berbeda-beda. Pemilihan subjek berdasarkan kriteria spesifik yaitu usia, latar belakang pendidikan, dan usia diharapkan akan menjadi variabel kontrol dalam penelitian. Pemilihan subjek berdasarkan kriteria spesifik tersebut perlu dilakukan karena latar belakang pendidikan, durasi memberikan perawatan, dan jenis kelamin adalah faktor yang mempengaruhi 
terbentuknya resiliensi. Selain itu perlu juga diperhatikan mengenai peran caregiver skizofrenia dalam merawat seperti anak, orangtua, pasangan (suami atau istri), adik atau kakak. Hal ini perlu diperhatikan karena masing-masing peran memiliki dinamika psikologis berbeda dalam membangun resiliensi.

Penelitian selanjutnya yang menggunakan pelatihan regulasi emosi perlu memperhatikan jumlah peserta pelatihan. Jumlah peserta pelatihan sebaiknya tidak lebih dari tujuh orang sehingga pelatihan menjadi lebih intensif dan efektif. Banyak sedikitnya peserta pelatihan juga mempengaruhi dinamika kelompok yang memberikan efek terapiutik bagi peserta pelatihan.

Berdasarkan data penelitian ini, ditemukan bahwa perubahan tingkat resiliensi sangat dipengaruhi oleh dukungan sosial dan koping spiritual yang dilakukan peserta saat menghadapi permasalahan dalam memberikan perawatan terhadap penderita skizofrenia. Oleh karena itu pelatihan mengenai dukungan sosial atau pelatihan spiritualitas cocok diberikan kepada caregiver skizofrenia untuk meningkatkan resiliensi.

\section{DAFTAR PUSTAKA}

Afiatin, T., Sonjaya, J. A., \& Pertiwi, Y. G. (2013). Mudah dan Sukses Menyelenggarakan Pelatihan. Yogyakarta : Kanisius
Afiatin, T. \& Haryanto. (2000). Efektivitas Pelatihan Program Kelompok "AJI" pada Guru Bimbingan dan Konseling. Jurnal Psikologi. No 1, 23-26

Akbar, Z. (2007). Efektivitas Pelatihan Manajemen Emosi sebagai Program Pemulihan untuk Mengatasi Depresi pada Remaja Korban Gempa Bumi Yogyakarta. Tesis (Tidak Diterbitkan) Universitas Gadjah Mada.

Ambari, P. K. M. (2011). Hubungan antara Dukungan Keluarga dengan Keberfungsian Sosial pada Pasien Skizofrenia Perawatan Rumah Sakit. Skripsi (Tidak Diterbitkan ) Universitas Diponegoro

Ancok, D. (2002). Outbound Management Training. Yogyakarta : UII Press

Ardiani, T. (2015). Pengaruh Pelatihan Regulasi Emosi dalam Meningkatkan Resiliensi pada Penderita Kanker. Skripsi (tidak diterbitkan) Universitas Islam Indonesia

Azwar, S. (2012). Reliabilitas dan Validitas. Yogyakarta: Pustaka Pelajar.

Bernard, M. E. (2008). The Effect of You Can Do I! Education on Emotional Resilience of Primary School Students with Social, Behavioural and Achievement Challenges. Proceesings of The Australian 
Psychological Society Annual Conference, 43, 36-40

Chan, S. W. (2011). Global Perspective of Burden of Family Cergivers for Persons with Schizophrenia. Archieves of Psychiatric Nursing, 339-349

Corey, G. (2007). Terjemahan. Teori dan Praktek Konseling dan Psikoterapi. Bandung : Refika Aditama

Corsini, R.J. \& Wedding, D. (2011). Current Psychotherapies $9^{\text {th }}$ Edition. Belmont : Brooks/Cole, Cengage Learning.

Cresswell, J. W. (2014). Research Design: Qulitative, Quantitative, and Mixed Methods Approches. Sage Publication.

Dale, S. K., Cohen, M. H., Kelso, G. A., Cruise, R. C., Weber, K. M., Watson, C., Burke-Miller, J.K., \& Brody, L. R. (2014). Resilience Among Women with HIV: Impact of Silencing the Self and Socioeconomic Factors. Journal of Springer Science, 221-231.

Darwin, P., Hadisukanto, G. \& Elvira, S. D. (2013). Beban Perawatan dan Ekspresi Emosi pada Pramurawat Pasien Skizofrenia di Rumah Sakit Jiwa. J Indon Med Assoc. 63 (2), 2033

Davidson, L., Schmutte, T., Dinzeo, T. \& Andres-Hyman, R. (2007), Remis- sion and Recovery in Schizophrenia: Practitioner and Patient Perspectives, Schizophr Bull. 2008 January; 34 (1): 5-8. Published online 2007 November 5. doi: $10.1093 /$ schbul/sbm122

Davey, Graham (2008). Psychopathology. British Psychological Society and Blackwell Publishing

Dolbier, C.I., Jaggars, S.S., \& Steinhardt (2009). Stress-Related Growth : Preintervention Correlates and Change Following Resilience Intervention. Stress and Health. Dipublikasikan secara online www.interscience. wiley.com.

Emilia, E. (2014). Pengaruh Terapi Rasional Emotif Perilaku dalam Meningkatkan Konsep Diri pada Wanita Obesitas Dewasa Awal. Tesis (Tidak diterbitkan). Universitas Islam Indonesia.

Fitrikasari, A., Kadarman, A., Woroasih, S. \& Sarjana, W. (2012). Gambaran Beban Caregiver Penderita Skizofrenia di Poliklinik Rawat Jalan RSJ Amino Gondohutomo Semarang. Medica Hospitalia. Med Hosp, 1 (2), 118-122. Fakultas Kedokteran Universitas Diponego-ro.

Dong, F., Nelson, C., Shah-Haque, S., Khan, A. \& Elizabeth Ablah. (2013). A Modified CD-RISC: Including Previously Unaccounted for Resilience Variables. Kansas Journal of Medicine 6 (1), 11-20. 
Greenberg, L.S. (2002). Emotion-Focused Therapy: Coaching Clients to Work Their Feeling. Washington DC: American Psychological Association.

Greenberg, L.S., \& Pascual-Leone, A (2006). Emotion in Psychotherapy: A Practice-friendly research review. Journal of Clinical Psychology Vol 62(5), 611-630

Gross, J. J. (2014). Emotion Regulation : Conceptual and Empirical Foundation. Handbook of Emotion Regulation $2^{\text {nd }}$ Edition. New York : The Guilford Press.

Hastjarjo, T.D. (2011). Validitas Eksperimen. Buletin Psikologi. Vol 19 (2), 70-80.

(2011). Kausalitas Menurut Tradisi Donald Campbell . Buletin Psikologi. 29 (1), 1-15.

(2014). Rancangan Eksperimen Acak. Buletin Psikologi. 22 (2), 73-86.

Heru, A. \& Drury, L. (2011). Developing Family Resilience in Chronic Psychiatry Illnesses. Medicine \& Health Rhode Island. 94 (2), 20-31.

Idaiani, S. (2003). Kecenderungan Depresi pada Keluarga Pasien Skizofrenia, Tesis (tidak diterbitkan), Universitas Diponegoro
Iswari, D. \& Hartini. N (2005). Pengaruh Pelatihan dan Evaluasi Self-talk terhadap penurunan tingkat Bodydissatisfaction. Insan Media Psikologi. 7 (3), 35-48.

Jain, A. \& Singh, D.C. (2014). Resilience and Quality of Life in Caregivers of Schizophrenia and Bipolar Disorder Patients. Globlal Journal of HumanSocial Science: A Arts \& HumatitiesPsychology. 14 (5) 44-58, Version 1.0. Online ISSN: 2249-460X \& Print ISSN: 0975-587X. Globlal Journals Inc.: United State of America

Kaakinen, J.R., Gedaly-Duff, V., Coelho, D.P. \& Hanson, S.M.H (2010). Family Health Care Nursing. Philadelphia : F.A. Davis Company

Keye, M.D. \& Pidgeon, A. (2013). Investigation of Relationship between Resilience : Mindfulness, and Academic Self-Efficacy. Open Journal of Social Science. 1 (6), 1-4.

Khairiyah, U. (2013). Pengaruh Terapi Dzikir terhadap Peningkatan Resiliensi pada Penderita Low Back Pain. Tesis (Tidak diterbitkan). Universitas Islam Indonesia.

Lestari, S. (2013). Psikologi Keluarga : Penanaman Nilai dan Penanganan Konflik dalam Keluarga. Prenada Media Grup.

Linehan, M. (2000). The Empirical Basis of Dialectical Behavior Therapy: 
Development of New Treatment versus Evaluating of Existing Treatments. Clinical Psychology : Science and Practice, 7, 113-119

Malkinson, R. (2007) Cognitive Grief Therapy: Constructing A Rational Meaning to Life Following Loss. New York : W.W. Worton

Makmuroch. (2014). Keefektifan Pelatihan Ketrampilan Regulasi Emosi terhadap Penurunan Tingkat Ekspresi Emosi pada Caregiver Pasien Skizofrenia di Rumah Sakit Jiwa Daerah Surakarta. Wacana Jurnal Psikologi. 6, 70-89.

Mennin, D.S. (2004) Emotion Regulation Therapy of Generalized Anxiety Disorder. Clinical Psychology and Psychotherapy, 1, 17-29

Min, J., S. Yoon., Lee, C., Chae. J., Lee. C., Song, K. \& Kim, T. (2013). Psychological Resilience Contributes to Low Emotional Distress in Cancer Patients. Journal of Springer Support Care Cancer 21, 24862476.

Min, J., Yu, J.J., Lee, C., \& Chae, J (2013). Cognitive Emotion Regulation Strategies to Resilience in Patients with Depression and/or Anxiety Disorder. Comprehensive Psychiatry. 54, 1190-1197.

Ni'mah, E. M. L., \& Sulistyarini, I. (2012). Efektivitas Pelatihan Regulasi Emosi untuk Meningkatkan Resiliensi pada
Ibu yang Memiliki Anak Autis. Jurnal Penelitian Psikologi. 3 (1), 89-102.

Ni, C., Chow, M.C.M., Jiang, X., Li, S., Mei, S. \& Pang, C. (2015). Factor Associated with Resilience of Adult Survivors Five Years after the 2008 Sichuan Earthquake in China. Plos One. March 26, 2015

Noe, R. (2002). Employee Trainingand Development. New York: McGrawHill.

Planalp, S. (1999). Comunicating Emotion: Social, Moral and Cultural Processes. Cambridge: Cambridge University Press.

Reivich, K., \& Shatte, A (2002). The Resilience Factors. New York: Broadway Books

Rutter, M. (2012). Resilience as a Dynamic Concept. Journal of Development and Psychopathology Cambridge University Press 24, 335-344.

Sadiq, S., \& Suhail, K (2013). Relationship of Expressed Emotion with Burden of Care and Health of Caregivers of Patients with Schizophrenia. Pakistan Journal of Social and Clinical Psychology. 11 (1), 3-10.

Salahuddin, M. (2009). Peran Keluarga terhadap Proses Penyembuhan Pasien Ganggguan Jiwa (Studi Kasus di Yayasan Dian Atma Jaya Lawang 
Kabupaten Malang). Skripsi: Fakultas Psikologi Universitas Islam Negeri

Seeman, M. V. (2012). Bad, Burden or III? Characterizing The Spouse of Women with Schizophrenia. International Journal of Social Psychiatry (0) 0, 1-6

Setyowati, C. (2015). Dinamika Psikologis Resiliensi Family Caregiver Orang Dengan Skizofrenia. Skripsi (Tidak Diterbitkan) Universitas Gadjah Mada.

Shibre, T. Kebede, D. Alem, A. Negash, A. Deyassa, N. Fekadu, A. Fekadu, D, Jacobsson, L. \& Kullgren, G (2003). Schizophrenia : Illness Impact on Family Members in a Traditional society -Rural Ethiopia. Social Psychiatry Psychiatric Epidemiol, 38:27-34. Diunduh dari www.link.springer.com

Shoviana, L. (2011). Resiliensi Keluarga Pasien Skizofrenia Pasca Diberi Psychoeducational Multifamily Group (PMFG). Skripsi (Tidak Diterbitkan) Universitas Negeri Semarang

Subandi, M.A. (2008), Ngemong: Dimensi Keluarga Pasien Psikotik di Jawa, Jurnal Psikologi volume 35, No I, 62-79, Fakultas Psikologi Universitas Gadjah Mada.

Subandi, M.A. \& Marchira, C. (2010). The Role of Family Empowerment and
Family Resilience on The Recovery of Psychotics Patients. ProcediaSocial and Behavioral Sciences, 116

Spiegler, M.D. \& Guevremont, D. C. (2010). Contemporary Behavior Therapy $5^{\text {Th }}$ Edition. Belmot: Wadsworth Cengage Learning.

Stuart, E.A. and Rubin, D.B. (2007). Best Practices in Quasi-Experimental Designs: Matching methods for causal inference. Chapter 11 (pp. 155-176) in Best Practices in Quantitative Social Science. J. Osborne (Ed.). Thousand Oaks, CA: Sage Publications.

Swaroop, N., Ravi, S., Goud,B.R., Archana, m., Pius, T., Pal, A., John, V., Agrawal, T., \& Jayaram, G (2013). Burden among Caregivers of Mental III Patient : A Rural Community - Based Study. International Journal of Research and Development of Health. Vol 1 (2). April 2013.

Syam, S. S (2013). Pelatihan Regulasi Emosi untuk Menurunkan Stress Caregiver Lansia. Tesis (Tidak diterbitkan). Universitas Islam Indonesia.

Tugade, M., \& Fredrickson, B (2007). Regulation of Positive Emotions : Emotion Regulation Strategies that Promote Resilience. Journal of Happiness Studies. 8, 311-333. 
Tugade, M., \& Fredrickson, B (2004). Resilient Individual Use Positive Emotions to Bounce Back from Negative Emotional Experience. Journal Personality and Social Psychology. 86 (2), 320-333

Troy, A.S., \& Mauss, I.B. (2011). Resilience and Mental Health : Challenges Across the Lifespan. Cambridge : Cambridge University Press

Vanderbilt-Adriance, E. \& Shaw, D. S. (2008). Protective Factors and the Development of Resilience in Context of Neighborhood Disadvantage. Journal Abnormal Child Psychology. Agustus. 36 (6) : 887901.

Widhiarso, W. (2011). Membuat Kategori Skor Hasil Pengukuran dari Skala. Materi kuliah. Fakultas Psikologi Universitas Gadjah Mada.Tidak diterbitkan.

Widuri, E.L. (2012). Regulasi Emosi dan Resiliensi pada Mahasiswa Tahun Pertama." Humanitas. 9 (2), 581595.
Windle, G., Bennet, K., \& Noyes, J. (2011). A Methodological review of Resilience Measurement Scale. Health and Quality of Life Outcomes, 9:8. http:/www.hqlo. com/content $/ 9 / 1 / 8$

Wu, G., Feder, A., Cohen, H., Kim, J., Calderon, S., Charney, D. \& Mathe, A (2013). Understanding Resilience. Frontiers in Behavioral Neuroscience. Vol. 7. Article 10. published 15 February 2013. www.frontiersin.org

Zauszniewski, J., Bekhet, A. \& Suresky, M.J. (2010). Resilience in Family Members of Person with Serious Mental Illness. Nursing Clinics of North America. 45 (4), 1110-1125.

Zauszniewski, J., Bekhet, A. \& Suresky, M.J. (2009). Effect on Resilience of Women Family Caregivers of Adult with Serious Mental Illness : The Role of Positive Cognitions. Archives of Psychiatric Nursing. 23 (6), 412-422. 